DOI https://doi.org/10.32405/2218-7650-2020-13(42)-24-37

UOT: $\mathbf{3 7 . 0 1}$

Verdiyeva Mehbanu Alimurad gizi,

PhD student of the

Azerbaijan State Pedagogical University.

Baku, Azerbaijan.

ORCID iD: https://orcid.org/0000-0002-0849-3933

rahimr0909@gmail.com

\title{
MODERN PEDAGOGICAL REQUIREMENTS TO THE TEACHER'S PROFESSIONAL COMPETENCE
}

Abstract. This article deals with the pedagogical requirements for the professional competence of a teacher who prepares a comprehensive schoolchild. The current state of education, the qualitative adaptation of the tasks set to it to the world level, the development of effective development programs that meet modern requirements for training are of concern to everyone. Raising the professional level of pedagogical specialists is already attracting more and more attention as an important problem to be solved. This problem, on the other hand, is of particular importance in connection with the dissemination of ideas of humanization of education, the educational process. In particular, the secondary school, which is responsible for directing schoolchildren to the professions, and the university, which is responsible for preparing them for the profession, are making serious efforts to clearly define the tasks facing them in modern times. However, it is also true that there are still a number of difficulties in achieving successful results. As a result, shortcomings in education as a whole, including the training of competent teachers, are manifesting themselves:

- educational results are not compatible with market conditions in terms of quantity and quality;

- the system of additional education does not meet the requirements of the day;

- ICT provision of the educational process lags behind the requirements of the day;

- the practice process, which better contributes to the formation of competencies, is not set up properly;

- there is no radical modernization in the training of pedagogical staff; 
- communicative relations between students and teachers are poorly developed;

- no serious attention is paid to students' self-education;

- insufficient use of psychological knowledge in the formation of professional skills in students;

- difficulties in teaching subjects by teachers with new technologies are obvious, etc.

Keywords: pedagogical requirements; quality; professional competence; modernity; staff training; professional ethics; subject-subject.

\section{INTRODUCTION / ВСТУП / ВВЕДЕНИЕ}

Formulation of the problem. In the computer age we live in, in the age of the internet, education, which is the foundation of science and high technology, needs structural change. Education also needs new research, equipment, and the provision of teachers who are well versed in the science of psychology. These needs should not be chaotic and fragmented, but a software strategy based on successful outcomes. As the new model moves towards education reform, family-school relations must also be brought to a modern level. The current state of education, which is qualitatively adapted to the world level, requires a high level of staff training based on the principle of competence and the development of effective programs for this purpose. For this, first of all, the forthcoming difficulties should be investigated and work should be done in this direction. In addition to modern education, the modern level of development of society also imposes a number of important tasks on the teacher. Thus, in order to see the success of their work, every teacher must communicate with students based on mutual respect, be demanding of their work and master the norms of ethical conduct.

Analysis of the latest relevant research and publications. M. Ilyasov, A. Alizade and H. Alizade, L. Amrahli, Ferstenmaher and Soltis, L. Gasimova and R. Mahmudova, A. Sherbakov's views are taken as a basis in the article. A. Alizadeh and H. Alizadeh`s "psychological portrait of a teacher» [3, p. 226], L. Amrahli's «ego-concept» [7, p. 1401], M. Ilyasov's classification of professional competence [6, p. 94] has a special place in research work.

\section{AIM AND TASKS / МЕТА ТА ЗАВДАННЯ / ЦЕЛИ И ЗАДАЧИ}

The purpose of this article is to examine and work on the challenges facing the development of high-level training and effective programs.

For this purpose, the article sets the following tasks: 
- to study the opinions of famous pedagogues;

- to study the requirements of modern education;

- to study the forthcoming difficulties for the development of effective programs;

- to investigate the difficulties in the field of personnel training.

\section{THE THEORETICAL BACKGROUNDS / TEOPETИЧНI ОСНОВИ ДОСЛІДЖЕННЯ / ТЕОРЕТИЧЕСКИЕ ОСНОВЫ ИССЛЕДОВАНИЯ}

The scientific-theoretical and methodological bases of the research work are the generally accepted principles and methods of the humanities. The National Curriculum Concept, the Education Reform Program of the Republic of Azerbaijan, the Education Sector Development Project, and the Assessment Concept are the concepts directly related to the research. The article is also based on the approaches to education and personality, education and social development, education and equality, and the principles of humanism, equality and quality.

\section{RESEARCH METHODS / МЕTОДИ ДОСЛІДЖЕННЯ / МЕТОДЫ ИССЛЕДОВАНИЯ}

Systematic approach method, content analysis, structural-functional analysis, comparative analysis, generalization methods were used in the research work. Comparative and systematic analysis methods were used to compare the education system, teacher competence, modern and traditional education systems. The sources used in the writing of the research work were approached on the basis of the principle of objectivity, books and articles of educational specialists from Azerbaijan, Russia, the United States, research conducted by prominent scientists were used as a theoretical and methodological basis. This analysis was carried out by examining the sources related to the topic, analyzing the results obtained there, analyzing and synthesizing the arguments put forward, as well as the method of comparative analysis.

\section{RESEARCH RESULTS / РЕЗУЛЬTATИ ДОСЛІДЖЕННЯ / РЕЗУЛЬТАТЫ ИССЛЕДОВАНИЯ}

Recently, rich and different opinions about teacher competence have been spreading in the pedagogical community. Each researcher strives to explain the basics, types, and characteristics of competence, and to communicate them to student and teacher audiences, in short, to the educational community. Among 
these riches of ideas, we also aim to summarize the modern pedagogical requirements for the professional skills of teachers.

These types of problems still exist in the professional training of students. Taking into account the realities, serious changes have taken place in recent years in the direction of restructuring the higher education system of the Republic. First of all, it should be noted that raising the level of professionalism of pedagogical specialists is already attracting more attention as an important problem to be solved. This problem, on the other hand, is of particular importance in connection with the dissemination of ideas of humanization and humanization of education, the educational process. The nature of pedagogical activity is gradually changing. For the development of education, the professionalism of educators: the diagnosis of knowledge, skills and competencies with new assessment standards (AS) is carried out. In short, in a developing society, the need for teachers who treat students humanely makes the development of teachers' professional competencies even more urgent.

The German Minister of Education and Research, Munch, states: «Many educators spend all their time, energy, and free time on their students. Good teachers have great responsibilities, creative potential and great love for their work and children at school» [1].

The teaching profession is, above all, adapted to the norms of moral behavior established in society. The current level of development of society makes it an important task for teachers to master a number of ethical norms of behavior. A teacher who wants to see the success of his/her work must be in a style of communication with students based on mutual respect, and be demanding of his/her work and students. He/she must forget any difficulties that faces in the pedagogical process, be a kind of actor, and patiently and discreetly choose the optimal solution to difficult situations. The teacher must be kind, fair and objective. If necessary, if he/she feels wrong in his work or in his attitude towards the student, he/she should try to eliminate it. In this way, he/she can play an important role in the moral education of students through his personal example. Following the teacher's example, students will try to be honest, admit their mistakes, and show interest in education.

In order to regulate the system of relations and responsibility for such behavior of teachers, the «Rules of Ethical Conduct for Teachers» were approved by the Order No 600 of the Ministry of Education of the Republic of Azerbaijan dated May 16, 2014. It is noted that these rules, consisting of 6 sections, have been developed in accordance with the Law of the Republic of Azerbaijan «On Education», as well as other legislative acts and the «Model of Ethical Standards for Participants in the Educational Process». This document serves to strengthen 
and regulate the education system at all levels of education. The main purpose of these Rules, which apply to teachers working in all types of educational institutions, is as follows [2]:

- establishment of a healthy business environment in educational institutions;

- increasing citizens' trust in educational institutions and teachers;

- ensuring closer involvement of parents and society in the management of educational institutions;

- increasing the efficiency and transparency of educational institutions;

- prevention of conflict of interest in the educational institution;

- achieving the prestige of teachers.

A. Alizadeh and H Alizadeh, speaking about the «psychological portrait of the teacher», emphasize the following: «The three-component teacher model is popular in American psychology. G. Lefransua's analysis is based on the research of Ferstenmaher and Soltis. They distinguish the following in the teacher's portrait: organizational model, therapeutic model, liberal model» [3, p. 226].

The authors also explain the essence of these models: «In the organizational model, lessons are valued as art. The effectiveness of the lesson is linked to the teacher's skill level. In the therapeutic model, the "happy" development of students is conditioned by the dimensions of students' health. The concept of education in the XXI century pays special attention to the health of students. In the liberal model, the teacher's teaching of reading to students is emphasized as an important psychological and pedagogical problem, these issues are studied in the context of development, special attention is paid to the development of "strategic thinking" in students» [3, p. 227].

L. Gasimova and R. Mahmudova comment on the pedagogical skills, habits and abilities of the teacher while talking about the features of pedagogical activity. "The proper organization of pedagogical activity also depends on the teacher's pedagogical skills and abilities. Thus, a teacher must have deep knowledge, creativity, broad thinking, but also be able to make his knowledge the property of students. A. Sherbakov grouped them as follows» [4, p. 166]:

- informative skills and habits;

- mobilization skills and habits;

- developmental skills and habits;

- directive skills and habits.

These authors also identified the abilities that are characteristic of teachers. These include: 

teacher);

- personal pedagogical abilities (characteristics and qualities of a

- didactic abilities (ability to explain, expressive-speech);

- organizational and communicative abilities (organizational, perceptive, suggestive, enlightenment).

S. Alizadeh approaches the issue in the context of «teacher's leadership style». He focuses on these issues. «Based on our theoretical analysis and initial empirical evidence, we can note a number of results related to the typology of teacher leadership style and which of these types of teachers in secondary schools are more appropriate» [5, p. 90].

Qualities related to the teacher's leadership style, which are directly related to the pedagogical process, the regulation of students' activities, their individual approach and developmental orientation, are considered expedient.

Teachers are more active, energetic and businesslike, but dependent on their own pedagogical activities. A quarter of teachers think that their pedagogical activity can be assessed as overly active, independent and enterprising.

Teachers working in the humanities prefer emotionally-motivated methods in individual work and judgmental methods in natural sciences.

Democratic style prevails in the management style of teachers as class leaders. This is followed by liberal and then authoritarian teachers

The pedagogical communication style is based on «dialogic», then «mutual trust», «noble», «monologue» and «influencing» styles, respectively.

S. Alizadeh also explains the reasons for the low individual capacity of teachers in management: inability to differentiate, poor organization, situational approach to issues; inability to work with documents, inconsistency in collecting and providing information related to the pedagogical process; to approach the assigned tasks on the principle of «everything will be solved by itself», to distance oneself from decision-making; reluctance to think about the problem and look for a solution; improper communication with subordinates, indifference to organizational work; to formally perform the functions belonging to him, to put forward endless and unrealistic ideas, to speak meaninglessly, to make uninteresting speeches; lifeless personal goals, not being clear to others or not being correspond to the real situation of these goals, not showing interest in acquiring relevant knowledge to solve the problem; inability to solve problems in accordance with modern economic conditions; inability to create new ideas, inability to influence people; management incompetence; inability to influence development, inefficiency of labor, etc. 
Because education is a constantly evolving field, teachers are required to raise their knowledge to a new level by constantly improving it. Therefore, in recent years, many additions have been made to traditional skills and competencies that apply to teachers. In this regard, it is important for a modern teacher to have 10 basic skills. These are also divided into two parts by their nature:

- traditional skills;

- new teaching skills.

Traditional skills refer to the knowledge, skills and qualities that are unique to a professional teacher from the earliest days of the teaching profession to the present day. Different divisions in this field are found in different literatures. The traditional skills that most researchers suggest are: organization, preparation, commitment, openness and readiness to ask questions, tolerance, storytelling, and so on. The new competencies include: innovation, passion for new technologies, social and geek technologies [6, p. 92].

Ilyasov in his work «Modern Problems of Teacher Professionalism and Pedagogical Competence» characterizes professional competence as a quality directly related to the content of the profession. From this point of view, it means that a teacher's professional competence should be complete at all stages of pedagogical activity. The teacher must show professionalism and competence in both the interaction with students in the teaching process and in extracurricular activities, as well as a competent approach to everything. «A teacher's professional competence not only eliminates all tensions in the pedagogical process, but also ensures the effectiveness of educational work. Not only the students, but also the teacher does not experience any nervous tension, stress or anxiety in the lesson taught by a competent teacher. In an experiment conducted by Rosenfeld, it was found that the behaviors of teachers who came to class, such as facial expressions, speech, activities, smiles, gestures and facial expressions, were almost twice as effective as those of unprepared teachers» [6, p. 94].

From the analysis of the literature we have conducted so far, we see that the approach to the skills to be formed in the student preparation process as a pedagogical process alone does not give effective results, because the structure of competencies is more related to psychological factors - habits, skills, abilities, psychological potential, system of actions. On the other hand, in the process of competency formation, we work more with the «student-subject» structure, rather than with the «student-individual», «student-personality» structure.

L. Amrahli approaches the issue from a different perspective. He considers it important to approach the issue in this direction in the training of personnel in 
the education system. «Regardless of the approach to the issue, the issue we are interested in here is the subject-subject of the teacher, which in modern times expresses the teacher's relationship with the student». A subject is a person or a collective who is actively developing, consciously perceiving himself/herself and the world around him/her. The subject, taking the initiative and independence, makes decisions and evaluates them, evaluates the results of his/her behavior, changes and improves himself/herself, and is able to determine his/her own multidimensional life prospects. The subject is accountable to himself/herself, to his/her actions, is able to realize himself/herself together with the "egoconcept", to be responsible» [7, p. 1401].

It is clear from the explanations that the subject is a broader concept that encompasses everything related to a person, in comparison with the individual and the person. "Subject is a general, broader and all-encompassing concept related to the natural, social qualities, individuality and personality of a person who is constantly evolving. Personality, on the other hand, is a lesser definition of human individuality. It is usually unnatural, it reveals its social potential» [7, p. 141].

It is clear that the role of the subject (teacher) in the exchange of modern information is to distinguish between the objective information, to distinguish those that are important for the life and activity of the subject (student). In our opinion, it is the individual who has the ability to generalize, interpret, form a working form, which is necessary for the practical life of the product, working effectively on information.

At this time, we are faced with the concept of self-regulation. The process of formation of professional skills takes place in the interaction of the two parties, ie in joint activity. The main point, the nucleus, the center is here.

Educators study the means and ways in which the processes take place there, and psychologists study the processes and mechanisms on the basis of which. Since we also approach the issue from a pedagogical point of view, we must prefer a psychopedagogical approach in order for the facts to be relevant and original.

The teacher's competent behavior, competent approach to pedagogical events and processes is also characteristic as an indicator of his/her pedagogical skills. A teacher's competent approach to both the teaching process and extracurricular activities has a direct impact on improving the effectiveness and quality of lessons and other activities. This is characterized, above all, by the teacher's innovative approach to the pedagogical process. A teacher's innovation is not only his/her mastery of new methods and modern technologies. The internal position created without being connected with the external 
environment, but the person's place in life, is connected with the internal motives. Such a reconstruction belongs to the individual as a whole. In ontogenesis, the motives associated with each component of a person's internal position, including motives, undergo many changes. Amrahli notes that subjectprofessional indicators of a teacher are: the teacher's internal position, motivation of professional activity, perception of himself/herself as a professional subject, self-assessment in terms of professionalism [7, p. 149].

Clearly, teaching is a daunting task all over the world. The honorable fulfillment of this obligation is the essence of his professional activity.

\section{CONCLUSIONS AND PROSPECTS FOR FURTHER RESEARCH / ВИСНОВКИ \\ ТА ПЕРСПЕКТИВИ ПОДАЛЬШИХ ДОСЛІДЖЕНЬ / ВЫВОДЫ И ПЕРСПЕКТИВЫ ДАЛЬНЕЙШИХ ИССЛЕДОВАНИЙ}

As a result of the analysis, we can say that the skills to be formed in the process of student preparation should not be approached as a pedagogical process, as the structure of skills is associated with more psychological factors habits, skills, abilities, psychological potential, system of actions. Not only in the pedagogical process, but also in the training of personnel in the education system, we should look at the process of formation of competencies not with the structure of «student-individual», «student-personality», but with the structure of «student-subject».

What has been said is that the primary aspect (competence) of a teacher who is willing and able to form pedagogical competencies in students is to approach students as subjects. To do this, he must know the age and individual characteristics of the student, the cognitive structure of what he needs to learn, master and do for professional activity. The subjectivity of both the student and the teacher should be expressed not only about themselves, but also in their attitude to knowledge and activity (activity).

The results of the study can be grouped as follows:

Mastering the theoretical and methodological knowledge of the pedagogical professional culture of the teacher, who is a leading force in the educational process, and mastering its basics. Of course, a teacher's knowledge of ethics, pedagogy, psychology, pedagogical psychology, psychopedagogy, age characteristics of children, the importance of the educational process, laws, principles and methods, as well as the cultural basis of education are the main conditions.

The teacher should pay attention to the subtleties of his / her professional activity to treat each student behind the desk with respect and humanity as an individual. Manistism in accordance with modern requirements is a quality 
inherent in the teaching profession, in its inner world.

Demonstration of the teacher in his / her daily pedagogical activity as a carrier of social and pedagogical skills in the educational institution. Here, the teacher fulfills an important mission not only as an intergenerational transmission, but also as a carrier of culture and mental values.

The teacher has a creative pedagogical understanding and is engaged in pedagogical creativity at a time when the perspectives are different. The rapid and high-level development of education in modern times, the reforms carried out require the teacher to have a new pedagogical thinking and not only to be satisfied with existing ones, but also to be inclined and engaged in pedagogical creativity.

In the era of high technologies, the teacher must master new pedagogical technologies, techniques and be able to apply them all in their pedagogical activities. This problem, which is a requirement of today, occupies an important place in the teaching profession. It is impossible to imagine a modern school without new information technologies, or a modern teacher without the ability to use them at a high level.

Prospects for further research: The analysis of this topic has also formed directions for future research in this direction. Thus, although various studies are conducted on this topic, in terms of the approach to students, certain nuances related to the development of the material and technical base of schools, as well as the professional competence of teachers are ignored. In particular, the fact that we live in an age of science and technology shows that change and development in education must meet the requirements of the time. Thus, the areas identified for future research can also be classified as follows:

- Inculcate a traditional education system in students based on the modern education concept.

- Organization of training programs abroad for teachers to acquire modern knowledge and skills.

- Conformity of teacher-student relations to modern requirements.

- Relevant experience in stimulating teachers 'pedagogical activity and students' success in the new educational process.

- Moral and psychological training of students.

- Increasing intellectual games.

- Demonstrate an open and tolerant attitude towards students for independent, creative, conscious activity.

- Ensuring the comfort of educational institutions in accordance with the approaches listed above. 


\title{
7. REFERENCES / СПИСОК ВИКОРИСТАНИХ ДЖЕРЕЛ / СПИСОК ЛИТЕРАТУРЫ (TRANSLATED AND TRANSLITERATED)
}

[1] Б. П. Яковлев, Л. А. Коваленко, «Технология формирования компотентности студентов», Современные исследования социальных проблем, № 1(21), 2013. [Электронный ресурс].

Доступно: https://cyberleninka.ru/article/n/tehnologiya-formirovaniyaprofessionalnoy-kompetentnosti-studentov/viewer

[2] Azərbaycan Respublikası Prezidentinin 2012-ci il 29 dekabr tarixli Fərmanı ilə təsdiq edilmişdir «Azarbaycan 2020: galacəyə baxış» inkişaf konsepsiyası. [Online]. Available: https://president.az/files/future az.pdf

[3] Ә. Ә. Olizadə, H. Ә. Olizadə, Әsrin meqameyllari: psixopedaqoji problemlar. Bakl, Azərbaycan: ADPU-nun mətbəəsi, 2008, cild II, 528 s.

[4] L. N. Qasımova, R. M. Mahmudova. Pedaqogika. Bakı, Azərbaycan: Çaşığlu, 2012, $548 \mathrm{~s}$.

[5] S. H. Olizadə, «Müəllimin məktəbdə rəhbərlik üslubunun sosial-psixoloji məsələləri», dis. ... elmlər doktoru. Bakı, Azərbaycan, 2015, 159 s.

[6] M. İ. İlyasov, Müallimin peşəkarlığı va pedaqoji sariştaliliyin müasir problemlari. Bakl, Azərbaycan: Elm və Təhsil, 2018, 208 s.

[7] L. Ş. Omrahlı, «Təhsil sistemində praktik psixoloq hazırlığında peşə səriştəliliyinin formalaşdırılmasının nəzəri və praktik əsasları», Təhsil Problemləri İnstitutu, Elmi-tədqiqat işi, Bakı, Azərbaycan, 2015, 63 s.

\section{СУЧАСНІ ПЕДАГОГІЧНІ ВИМОГИ ДО ПРОФЕСІЙНОЇ КОМПЕТЕНЦІЇ ВЧИТЕЛЯ}

\author{
Вердієва Мехбану Алімурад гізі, \\ докторант Азербайджанського \\ державного педагогічного університету. \\ Баку, Азербайджан. \\ ORCID iD: https://orcid.org/0000-0002-0849-3933 \\ rahimr0909@gmail.com
}

Анотація. У статті розглядаються педагогічні вимоги до професійної компетентності вчителя, який готує загальношкільного школяра. Стан сучасної системи освіти, якісна адаптація поставлених перед нею завдань до світового рівня, розроблення ефективних програм розвитку, що відповідають останнім вимогам, турбують усіх. Підвищення професійного рівня педагогічних фахівців - важлива проблема, яку потрібно вирішувати. Ця проблема має також особливе значення через поширення ідей гуманізації освіти, освітнього 
процесу. Середня школа, що відповідає за спрямування школярів до професії, та університет, що відповідає за підготовку їх до цієї професії, докладають серйозних зусиль для того, щоб чітко визначити завдання, які стоять перед ними у сучасний час. Однак виявляються серйозні недоліки в системі освіти, зокрема, це стосується підготовки компетентних викладачів:

- результати освіти несумісні з ринковими умовами за кількістю й якістю;

- система додаткової освіти не відповідає вимогам дня;

- ІКТ-забезпечення освітнього процесу відстає від сучасних вимог;

- процес практики, який краще сприяє формуванню компетентностей, не налагоджений належним чином;

- відсутня радикальна модернізація у системі підготовки педагогічних кадрів;

- комунікативні стосунки між учнями та викладачами розвинені слабо;

- не приділяється належна увага самоосвіті учнів;

- недостатньо використовуються психологічні знання в процесі формування в учнів професійних навичок;

- труднощі у викладанні предметів викладачами за новими технологіями очевидні тощо.

Ключові слова: педагогічні вимоги; якість; професійна компетентність; сучасність; підготовка персоналу; професійна етика; предмет-предмет.

\title{
СОВРЕМЕННЫЕ ПЕДАГОГИЧЕСКИЕ ТРЕБОВАНИЯ К ПРОФЕССИОНАЛЬНОЙ КОМПЕТЕНТНОСТИ УЧИТЕЛЯ
}

\author{
Вердиева Мехбану Алимурад гызы, \\ докторант Азербайджанского \\ Государственного Педагогического Университета. \\ Баку, Азербайджан. \\ ORCID iD: https://orcid.org/0000-0002-0849-3933 \\ rahimr0909@gmail.com
}

Аннотация. В статье рассматриваются педагогические требования к профессиональной компетентности учителя, готовящего школьника общеобразовательной школы. Состояние современной системы образования, качественная адаптация поставленных перед ним задач к мировому уровню, разработка эффективных программ 
развития, отвечающих современным требованиям, беспокоит каждого. Повышение профессионального уровня педагогических специалистов - важная проблема, которую необходимо решать. Эта проблема приобретает особое значение также в связи с распространением идей гуманизации образования, образовательного процесса. Средняя школа, отвечающая за то, чтобы направить школьников к профессии, и университет, отвечающий за их подготовку к профессии, прилагают серьезные усилия для того, чтобы четко определить задачи, стоящие перед ними в современное время. Однако существуют серьезные недостатки в системе образования, в частности, это касается подготовки компетентных преподавателей:

- образовательные результаты несовместимы с рыночными условиями по количеству и качеству;

- система дополнительного образования не отвечает требованиям дня;

- ИКТ-обеспечение образовательного процесса отстает от современных требований;

- не налажен процесс практики, который лучше способствует формированию компетенций;

- отсутствует коренная модернизация в процессе подготовки педагогических кадров;

- коммуникативные отношения между учениками и учителями развиты слабо;

- не уделяется серьезное внимание самообразованию студентов;

- недостаточно используются психологические знания при формировании профессиональных навыков у студентов;

- сложности в преподавании предметов учителями с новыми технологиями очевидны и т. п.

Ключевые слова: педагогические требования; качество; профессиональная компетентность; современность; подготовка кадров; профессиональная этика; предмет-предмет.

REFERENCES / TPAНСЛИTЕРАЦИЯ (TRANSLATED AND TRANSLITERATED)

[1] B. P.YAkovlev, L. A. Kovalenko, «Tekhnologiya formirovaniya kompotentnosti studentov», Sovremennye issledovaniya social'nyh problem, № 1(21), 2013. [Elektronnyj resurs]. 
Dostupno: https://cyberleninka.ru/article/n/tehnologiya-formirovaniyaprofessionalnoy-kompetentnosti-studentov/viewer

[2] Approved by the Decree of the President of the Republic of Azerbaijan dated December 29, 2012 «Azerbaijan 2020: vision for the future» development concept. [Online].

Available: https://president.az/files/future az.pdf

[3] A. A. Alizade, H. A. Alizade, Megamels of the Century: psychopedagogical problems. Baku, Azerbaijan: ADPU printing house, 2008, vol. II, 528 p.

[4] L. N. Qasımova, R. M. Mahmudova. Pedagogy. Baku, Azerbaijan: Chashyoglu, 2012, 548 p.

[5] S. H. Alizadeh, «Socio-psychological issues of the teacher's leadership style at school», dis. ... Doctor of Sciences. Baku, Azerbaijan, 2015, 159 p.

[6] M. İ. Ilyasov, Modern problems of teacher professionalism and pedagogical competence. Baku, Azerbaijan: Science and Education, 2018, 208 p.

[7] L. Ş. Amrahli, «Theoretical and practical bases of formation of professional competence in the training of practical psychologists in the education system», Institute of Educational Problems, Research work, Baku, Azerbaijan, 2015, 63 p. 